\title{
EVALUATION OF INVESTMENT INCENTIVE POLICY IN THE FORM OF TAX HOLIDAY IN ORDER TO INCREASE INDONESIAN ECONOMIC GROWTH
}

\author{
Resha Dwiayu Pangesti Mulyono \\ Master of Accounting-Airlangga University \\ Surabaya, Indonesia \\ reshadwiayu@gmail.com
}

\author{
Elia Mustikasari \\ Departement of Accountancy-FEB \\ Airlangga University \\ Surabaya, Indonesia \\ elia-m@feb.ac.id
}

\begin{abstract}
This study aims to evaluate investment policy in the form of tax reduction facilities as a result of the slowing down of the economic sector and the impact of global business competition resulting in a decline in foreign investor confidence in investing in Indonesia. This research was done in the form of qualitative research type using an exploratory study. The data collection technique used was preliminary surveys, direct interviews and direct observation with the policy actors. The results showed that tax investment policy in the form of tax holidays indicate that the tax incentive policy in Indonesia has little impact on the increase of economic growth. It is proven that there are regulations that do not yet reflect the efficiency of foreign investors for the industrial discrepancies set by the Government in stimulating investment and human resource limitations in relation to the Directorate General of Taxes.
\end{abstract}

Keywords: Investment Incentives, Tax Holiday, Indonesian economic growth

\section{BACKGROUND}

Indonesian economic conditions nowadays have been facing massive challenges from the global economy, one of which is shown by the global economic growth noted by the World Economic Outlook (WEO) in 2016 from the initial achievement of $3.1 \%$ to $3.3 \%\left(\mathrm{y}_{\mathrm{o}} \mathrm{y}\right)$ indicating a decrease in global economic optimism in 2016, compared to the previous year. This outlook decrease is followed by a decrease in other trade commodities as well as slowing economic growth in developed countries, like Tiongkok, Japan, and Europe, and in developing countries in the ASEAN region. The global economy also impacts on the domestic economy, which is reflected in the fact that the current balance deficit is at its lowest level in the past five years, which is at $0.8 \%$ of the GDP in the fourth quartile which is due to the strengthening of the manufacturing exports (Worldbank, 2016). According to Rixen's view (2008) about politics, valuable moves have been done to help forward the global business competition in a country which is known as tax competition. In the field of public economy, one of the fiscal issues in tax competition is about creating efficiency. An efficient tax competition may use models of economy which are aimed at exclusively evaluating the tax competition in one dimension (Genschel, 2011).
In the history of the Ministry of Industrial Affairs (2012), tax holiday once existed in Indonesia's taxes, regulated in Act No. 1 of 1967 jo Act No 11 of 1967 about Foreign Investment which stated all kinds of tax indulgences. Three years after, which was in 1970 , provisions regarding tax holidays ended in failure. This was due to its failure to comply with the government's target. The policy on tax holidays in Indonesia was waxed and waned until 2017 , based on the data from the Ministry of Industrial Affairs (2017). It is noted that only five companies have received such facilities with a total investment of $\mathrm{Rp} 38.5$ trillion. In fact, some pros and cons regarding the policy, especially that of the tax holiday, are in the form of profit-based tax insentivity, meaning that the benefits are available so long as the respective companies note down their profits. Thus, should a country wish to draw foreign direct investment out of the business sector which presumably tends to have low profits but can cover a lot of people' needs, the tax holiday may not be appropriate (Darussalam et al., 2015).

On the other hand, Botman et al. (2010) suggests that a tax holiday is the most attractive method of attracting investment with high profits. It may not always create redundancy which is dependent on the respective company's profit and the average taxes rate effectiveness conforming to other countries which also is an attempt to attract investment. In addition to the above, miscoordination in the process of the distribution of income tax reduction is also an issue which is related to views among the Directorate General of Taxes, the Ministry of Industrial Affairs and the Capital Investment Coordinating Board, resulting in delays in the process of facility utilisation approval (Nizaldy, 2014).

According to the aforementioned description, this study aims to conduct an evaluation of the tax holiday policy applied in Indonesia from 2011 - 2016. This has been investigated conceptually, theoretically, and practically in accordance with the field conditions. Employing the theory of policy evaluation in describing the administration improvements will increase the investment and enhance the development, thus the distribution of infrastructure development and Indonesian economic growth can be achieved by conducting the designed evaluation method. 


\section{LITERATUR REVIEW}

\section{A. Policy Evaluation Theory}

Policy evaluation, as suggested by Dunn (2000), consists of four criteria as presented in the following table:
1. Effectivity;
2. Efficiency;
3. Responsitivity;
4. Accuracy;

\section{B. Investment Incentives}

Generally, tax incentives implemented in a country, according to Easson (2004), can be in the form of income tax reduction for certain activities or businesses, tax amnesty, tax credit for capital goods in investment, accelerated depreciation for capital goods and a higher cost acknowledgement than the actual cost which is used as an income reducer, withholding tax reduction of profits returned to the host country, individual tax reduction and/or allowances for civil servants, exception or reduction of Value Added Tax or Sales Tax, reduction of Land and Building Tax, or the reduction of Customs and Excise.

\section{RESEARCH METHOD}

This is a qualitative study employing a case study design within an exploratory study, or explorative as defined by Kotler and Lane (2006). This study's objective is focusing on the policy of investment incentives in the form of the tax holiday facility awarded by the Indonesian Government to foreign investors which aims to support the Government in reducing the unemployment rate and creating new technology.

\section{Data Collection Technique}

- In studies on the investment policy evaluation of tax holidays in Indonesia, in order to enhance foreign economic growth, it requires relevant records and documents to support the study.

- According to Indriantoro and Supomo (2011a), direct interviews were addressed to the policy implementers: the Staff Directorate General of Taxes, the Capital Investment Coordinating Board (Directorate of Deregulation), Tax Consultants and the Indonesian Employer Association.

- Direct observations, as defined by Basuki (2016), are passive observations in which a researcher observes activities within a study site. In this type of observation, a direct interaction with the informants through field studies and by going directly to the OneDoor Integrated Center in Jakarta.

Data Analysis Technique

The data obtained from the in-depth interviews and information found in the field observation underlies the analysis process in this investigation.

\section{RESULTS AND DISCUSSION}

Evaluation of the Investment Incentives Policy of Tax Holidays towards the Increase in Economic Growth

The evaluation of a policy focuses on assessing things related to needs or the value of that certain policy and program. A prominent evaluation is an attempt to define the advantages and uses of a social policy or program, and not a mere attempt to collect information related to both the anticipated and unanticipated results of policy implementation. Since the precision of the objectives and targets of policies are always open to questioning, an evaluation may cover the procedures intended to evaluate the objectives and targets.

\section{Assessment on Effectiveness of Tax Holiday Policy}

The existence of tax incentives in the form of a tax holiday is not a primary policy to stimulate th investment climate in Indonesia, but it is a complementary policy to attract foreign investors, especially to eventually improve the Indonesian economy, making such policy remain a consideration for the government to make foreign investors invest in Indonesia, despite how small of an impact it could bring. In fact, the tax holiday policy constitutes the tax regime that is commonly done in developing countries, like Indonesia.

Having observed employment absorption from 2011 until 2016, the new established field work achieved 21.843 projects with a total realisation of $\mathrm{Rp} 453,4$ trillion or $76.2 \%$ of the realisation target of investment. Dominantly, the realisation value emerges from foreign investment, which is Rp 309.623 trillion. Labour intensive investment (textiles and shoes) has successfully absorbed direct employees totaling 153.400 people or about $16 \%$ of the new fieldwork has been opened. From investors, the contribution is projected to achieve 1.25 million of the fieldwork per year.

Actually, the tax holiday policy does not aim to be a labour intensive investment, as it is regulated in Minister of Finance Regulation No. 103/PMK.01/2016 stating that pioneering industries do not focus on labour intensive industries, but on certain sectors such as upstream metals, telecommunications, and the information and communication industry. Currently, the tax holiday policy is not the main priority in absorbing employment because its main objective is to support the government in national economic growth by incorporating upto-date technology and accelerating infrastructure development with conditions as stated in the regulation, as it explains the minimum impact towards employment absorption in Indonesia.

According to Musgrave and Peggy B Musgrave (1989), the overly given tax incentives may result in distortions in the business competition, such as:

\section{a. Distortion in business decisions}

In several cases, tax incentives may stimulate a company to act in such a way that causes inefficiency in resource allocation. In another case, tax incentives do not affect a company's attitude, thus rewards are given to the company, whereas the company would still do the same thing without such a reward. 


\section{b. Distortion in business competiton}

Another kind of distortion impacted by the tax incentive policy is that between companies receiving and not receiving incentives. Such cases would cause interruptions in the economy.

\section{Assessment on Efficiency of Tax Holiday Policy}

In its relationship with the investment incentives policy, including the facility of tax reduction, it belongs to a series of national industrial development policies; therefore, by giving such incentives, the efficiency, competitiveness and exports of industrial products can be enhanced. Should a certain perception be built, in the short-term, the state will lose its income but the tax reduction can be compensated by creating more jop opportunities, cutting down on the number of poverty, accelerating infrastructure development, and improving societal welfare by supporting every policy issued by the Government.

Around $26 \%$ of the reforms implemented in the expanded indicator sets were only made in the new areas. The other $17 \%$ concerns both the new and old indicators. Indeed, over $40 \%$ of all of the reforms affected at least one of the components added since Doing Business 2015. The frequency of the reforms in the new areas varies substantially by topic, with the most reforms occurring within the enforcing contracts and registering property indicators. In registering property, for example, this year the cadastral maps have been digitised and made available online in Jakarta and Surabaya, Indonesia (Doing Business, 2017).

\section{Assessment on Responsitivity of Tax Holiday Policy}

The policy evaluation on responsitivity encompasses the policy outcomes which satistify the prefered needs or values. Such a policy outcome can be observed from the response of the receiver or from those who are benefitting from the policy. By the beginning of 2017, based on the data from the Ministry of Industrial Affairs (2017), five out of 11 companies have been approved for tax holiday, while the rest are suggested to join the tax incentives program of tax allowance.

Table 1. List of Receivers of Tax Reduction Facility (Tax Holiday)

\begin{tabular}{|l|l|l|}
\hline No. & \multicolumn{1}{|c|}{ Nama Perusahaan } & \multicolumn{1}{|c|}{$\begin{array}{c}\text { Nilai Investasi } \\
\text { (Rupiah) }\end{array}$} \\
\hline 1. & PT Ogan Komering Ilir Pulp \& Paper Mills Tbk. & 29 Triliun \\
\hline 2. & PT Unilever Cleochemical Indonesia Tbk. & 1,15 Triliun \\
\hline 3. & PT Petrokimia Butadiene Indonesia Tbk. & 1,3 Triliun \\
\hline 4. & PT Synthetic Rubber Indonesia & 4,6 Triliun \\
\hline 5. & PT Energi Sejahtera Mas & 2,8 Triliun \\
\hline \multicolumn{2}{|l}{ Sumber: Kementerian Perindustrian (2017) }
\end{tabular}

Table 1 describes that from 2011 to 2016 , only a minimum number of tax receivers registered, which has not yet achieved the government target to attract more foreign investors so that the investment cost in Indonesia can be increased, as a result of the high investment cost set in the provisions. This is because of some considerations which underly the
Government's decision whether to give the facility or not, like the fulfillment of administrative requirements regulated in the most recent regulation, which is PMK 103/PMK.010/2016 in which revisions were made from PMK 130/PMK.011/2011, with the proposal time efficiency being 20 days in BKPM once the requirements are satisfied.

The minimum number of responses also indicates that the tax holiday policy is not a primary consideration for new investors for making the investment decision, as proven in the report of World Bank Ease of Doing Business (2017) that shows that taxes are in the seventh place as a priority for investors to take a decision.

\section{Assessment on Accuracy of Tax Holiday Policy}

Basically, a tax holiday is a form of tax policy that is not supported with legal certainty, as it is not being mandated by an Income Tax Act, thus there is no legal certainty offered for Fiscus and Tax Payers. For the Fiscus, which in this context refers to the Directorate General of Taxes, they are obliged to perform in their tax area, yet in fact, there is no such legal certainty, whether it is supported by the laws on Income Tax Act or Capital Investment Act or not, making tax payers hesitate. Should double and conflicting regulations against the Income Tax Act exist, legal uncertainty will emerge.

Theoretically, the tax authorities can set prices at arm's length and re-allocate profits between the area of tax and those areas that are not to be shared by the companies. It has been proven to be almost impossible in practice. When the tax administrators attempt to cope with such matters, they should employ certain regulations rather arbitrarily. As a consequence, they also increase perceptions about the less transparent bureaucracy which may inhibit investment.

\section{Constraints of Implementation of Investment Incentive Policy of Tax Holiday}

\section{For the Government}

This policy manifests in tax incentives to do with Income Tax reduction. Constraints and obstacles may happen in the policy aspect and technical aspect of the implemented policy. The constraints and obstacles faced during the implementation by the government is to do with time limitations. Time here refers to the period of formulating policies and informing or socialising the policy to the beneficiaries, namely Textile Industries, in which the government should socialise the policy in order to facilitate the objective's achievement.

On the other hand, different points of view still occur within the government, like the Ministry of Industrial Affairs and the Ministry of Finance. For the Ministry of Finance, on the one hand, tax holidays have a loss potential, while for us it has revenue potential. At the time, I invested in Indnesia within the range of 5 to 15 years, they are given free facilities. Nonetheless, after 20 years, these industries become subject to taxes. When we invest here, there must be employee absorption, sales and imports, so that other types of tax can be examined, not Income Tax but Value Added Tax. 


\section{For Industrial Companies}

The government cannot be mistaken for having made the tax incentive investment, for they intend to push the investors to make their investment in eight areas of the pioneering industries determined beforehand. It does not matter for the companies either, but such a policy should not be put too much expectation in to, or become a solution to attract more investors permanently. Tax holidays targeted by investors are true in advanced countries because there is the giving of tax incentives that have been proven to be good and advanced. Not all industries are involved. Yet, what needs to be taken into consideration is how to increase the tax ratio, tax base and to fill in more slots in the budget deficit.

\section{CONCLUSIONS}

Basically, tax holidays are a form of tax policies that are not supported with legal certainty, as it is not being mandated in the Income Tax Act. No legal certainty is offered for the Fiscus and Tax Payers. Minimum responses also indicate that the tax holiday policy is not a primary consideration for new investors when making the investment decision, as proven in the report of World Bank Ease of Doing Business (2017) that showed that taxes are in the seventh place of priority for investors to make a decision. Incentives and depreciation requested is among the others; the depreciation of direct taxation to pioneering industries which have proposed such a facility is considered short-term efficiency. Tax reduction incentives are not yet effective enough to absorb more employees and have not contributed significantly to national development. This policy is also done to make the capital expenditure and operational expenditure more efficient, and to improve the optimisation of investment activities, employment absorption and infrastructure development acceleration. Because in fact, the tax holiday policy constitutes the tax regime that is commonly done in developing countries, like Indonesia.

\section{SUGGESTIONS}

1. Further investigation on the legal certainty related to more appropriate investment incentive policies for tax holidays, such as the study on pioneers which are intended to achieve more employement absorption, and to help accelerate infrastructure development considering such a great amount is being invested, such as in tourism, labour intensive or other priotised industries.
2. The policy implementers, like the Indonesian Employment Association, Indonesian Chamber of Commerce, taxation reviewers and academics can work hand in hand to monitor any success or failure of an investment policy to fulfill the market demands and to create a more conducive business climate without being over-distorted by the Government and the receivers of the tax reduction facility.

3. The Indonesian Government should be able to offer security assurances, legal certainty, political stability and investment services continuously to foreign investors so that the faith in Indonesia as a developing country worth the investment is strengthened by building coordination between institutions or the Ministry.

\section{References}

[1] Basuki. (2016). Metode Penelitian Akuntansi dan Manajemen Berbasis Studi Kasus. Surabaya: Airlangga University Press.

[2] Botman, D., Klemm, A., \& Baqir, R. (2010). Investment incentives and effective tax rates in the Philippines: a comparison with neighboring countries. Journal of the Asia Pacific Economy, 15(2), 166-191.

[3] Darussalam, Kristiaji, B. B., \& Mukarromah, d. A. (2015). Dilema Tax Holiday. Inside Tax.

[4] Doing Business Ease. (2017). Equal Oppurtinity for All, a World Bank Group Flagship Report. Washington: World Bank Publication.

[5] Easson, Alex (2004). Tax Incentives For Foreign Direct Investment. Netherlands: Kluwer Law International.

[6] Genschel, P., \& Schwarz, P. (2011). Tax competition: a literature review. Socio-Economic Review, 9(2), 339-370. Economic Journal, 59, 4.

[7] Indriantoro, N., \& Supomo, B. (2011). Metodologi Penelitian Bisnis Untuk Akuntansi dan Manajemen, Edisi Pertama. . Yogyakarta: BPFE.

[8] International Monetary Fund. (2016). World economic outlook database.

[9] Musgrave A., Richard and Peggy B Musgrave. (1989). Publik Finance in Theory and practice. New York: Mc Graw Hill Company.

[10] Nizaldy, Rendy. (2014). Evaluasi Kebijakan Investment Allowance Berdasarkan Prinsip-Prinsip Kebijakan Pajak. Jurnal Fisip UI.

[11] PRixen, T. (2008). The political economy of international tax governance: Springer.

[12] http://www.bkpm.go.id/id/investasi-di-indonesia/statistik / Access on 12 February 2017

[13] http://www.kemenperin.go.id/ Access on 7 April 2017

[14] http://data.worldbank.org/indicator/ Access on 15 February 2017 